\title{
ASKHAN FATHUTDINOV IN CONTEMPLATION OF THE MYSTERIES OF THE UNIVERSE (EXPERIENCE OF A HERMENEUTICAL ANALYSIS OF THE PAINTING "OMET" ("HOPE"))
}

\author{
Svetlana Viktorovna Sintsova, \\ Apt. 19, 7 Chistopolskaya Str., Kazan, 420066, Russian Federation, \\ esintsov@mail.ru.
}

\begin{abstract}
The article outlines a new approach to determining original features of Askhan Fathutdinov's paintings, i.e. the research into the system of meanings in his works. The necessity and productivity of this hermeneutical approach is justified by an in-depth study of his picture "Omet" ("Hope").

A comprehensive analysis of the subject, image system, expressive and visual means, possible reactions of the recipient allowed us to make a conclusion about a complex, philosophically and mystically oriented system of meanings that convey a deep and dynamic world of the artist's original ideas about the meaning of human existence, its values, the continuity of generations based on these values, about mysterious forms of a dialogue between people with otherworldly, mystical dimensions that eternally accompany earthly existence, and even about the relationship between the province and the capital...

Such observations made it possible to draw parallels of A. Fathutdinov's artistic discoveries with the ideas of existential philosophers, and to establish the boundaries of possible analogies.

The article also presents the main facts of A. Fathutdinov's biography and highlights the most characteristic features of his artistic style.
\end{abstract}

Key words: painting, Askhan Fathutdinov, painting "Omet" ("Hope"), hermeneutical analysis, comprehensive method, existentialism, mysticism, existence, Allah, Tengri.

The works of A. Fathutdinov present both attractive and complex subject for a scientific analysis. At first glance, they are simple and even unpretentious. This deceptive outward appearance is created by pieces of wood, barely processed, cracked, old, which would most likely be used as firewood for the stove in everyday life. However, the artist, having slightly altered it, having cleared it from bark, used it for sculptures, panels, for strange frames, either framing pictures, or intruding into a painting canvas. What is more, his paintings match his sculptures: without frills and fads, in the manner of a primitive art fashionable in the recent past. Neither the subject matter of his works is striking with innovation and refined choice: pagan images of spirits, deities, Biblical motifs (Adam and Eve, a transformed cross for crucifixion), details and scenes of rural life. A soft palette only increases the feeling of simplicity, naturalness, and unassuming attitude. The colors seem to echo the shades and texture of the wood that frames the paintings. This creates a curious effect, which has been noticed by art historians more than once: these are the windows from which a villager looks at something intently or accidentally, sees something out of the corner of his eye, suddenly catches sight of.
An art critic who analyzes these creations has nothing to specify. The manner of paintings is recognizable and secondary in the context of world art areas and trends: "belated modernism", as this feature of Tatarstan painting is defined by Yu. G. Nigmatullina in the title of her monograph [Nigmatullina, 2002], R. R. Sultanova calls it primitive and socialistic art [Sultanova, p. 59]. S. M. Chervonnaia (1974) [Chervonnaya], F. Kh. Valeyev (1984) [Valeyev], G. F. ValeyevaSuleymanova (1984) [Valeeva-Suleymanova], A. B. Feinberg (1983) [Feinberg] describe A. Fathutdinov as an artist whose work is organically interwoven into the main trends of fine arts.

Only his cycle "Iyalar" (The Amulets), which presents humanized images of spirits [Valeeva], is quiet unusual in the context of artistic trends and creative searches of Tatarstan's artists ([Nigmatullina, 2011], [Nigmatullina, 2014], [Nigmatullina, 2015], [Sultanova, 2001], [Chervonnaia, 1998], etc.)

R. Shageeva pays special attention to this cycle in her analysis in the article, preceding A. Fathutdinov's album of works (2002) [Shageeva, pp. 5-13]. Her introductory article to the publication of the artist's reproductions (2002) summarizes the main observations of art historians and their 
attempts to identify the most characteristic features of his work.

The "light sorrow" as a general emotional tone, the whole work executed in human terms, gravitation towards philosophy, cosmism, and "literature", the national color of images (folklore, mythological images, "the whole system of Tatar culture") are marked among the main features of the artist and sculptor's heritage. R. Shageeva highlights the dialogue among cultures (mainly with "ancient civilizations") and defines the main conflict of the artist's works, i.e. between man and nature; she reveals some features of the artistic language, i.e. the symbolism of color, carving and writing techniques, the making of frames. Thus, $\mathrm{R}$. Shageeva outlines a number of aspects for the study. Her article can be considered a detailed monograph prospectus.

Undertaking such a comprehensive review of A. Fathutdinov's work, R. Shageeva seeks to distinguish and emphasize the originality of his works, which undoubtedly is the task of the introductory article to the publication of reproductions. However, of the features listed and noted by her, the shades of uniqueness are peculiar, perhaps, only to various folklore and mythological characters, whose images the artist painted so often, and to the huge role of wooden details, which he often added to the images in the paintings. The indirect confirmation of this is the extensive material presented in the above-mentioned monograph by R. Sultanova [Sultanova]. Almost all the features of A. Fathutdinov's work, outlined by R. Shageeva, can be found in the works of his contemporaries from the "new cities" of Tatarstan: the dialogue among cultures, the conflict between man and nature, cosmism, literature, images of Tatar folklore, experiments with artistic expression, etc.

In the light of such traditional scientific approaches, the work of A. Fathutdinov does not look too original and noticeable, it easily fits into the Procrustean bed of art criticism cliches that create the image of a marginal artist, although not uninteresting, who fits in the context of creative searches of "the artists from new cities of the Republic of Tatarstan". Many of them also sought for various techniques and ways to combine elements of national art with "belated modernism" innovations, forebodings of social and spiritual changes in society, and the discovery of new themes in painting and sculpture. They did it in a bright, original and dignified way, achieving a high level of skill, artistic expression, and a large-scale depth of meanings.
A. Fathutdinov, undoubtedly, belongs there, he is in the same row, however, strangely out of it. This sculptor and painter has something unique and individual, something that imparts an uncommon expression to his creative works.

This aura of his creations is involuntarily felt in slow and thoughtful contemplation. His paintings do not merely attract the eye, they encourage a long and close examination. They invite you to unknown worlds, present unseen creatures, strangely transformed faces and figures of people, images of animals, birds, and details of everyday life to the viewer. Behind these transformations and distortions, you can discern not only the artist's riot of imagination, but also a quiet, although passionate desire to tell his viewers something, to share with them his secret knowledge about life, about the Gods, about fairy-tales and mystical dimensions. The frames of his paintings invite you to come closer and look carefully at what is invisible in ordinary life, but perhaps is secretly present in unknown dimensions of being.

In this way, A. Fatkhutdinov tries to awaken not just a childish curiosity, but also to activate the viewer's intuition, pre-rational knowledge, inherited from ancient eras. The artist skillfully creates conditions for an in-depth multi-dimensional dialogue with the viewer, who is allowed to plunge into the images and worlds of the author, to feel and guess the hidden current of his thoughts and states of mind. Only then, an almost boundless horizon of complex and intense attempts of the author to guess and express some deep knowledge about the world, man, God, otherworldly beings and inhabited mysterious spaces opens up before the surprised attentive beholder. Behind the apparently simple and inelaborate plot, behind the dimness of the palette, the most complex dynamics of meanings is revealed, which is characteristic only of high artistic creations of the human spirit. The interweaving of meanings sometimes reaches large-scale generalizations, approaching the understanding of the eternal mysteries of existence, their philosophical (but never rationalistic) comprehension.

The names themselves suggest plunging into these complex and multidimensional horizons of meanings: "Youth. Old Age", "Naz" ("Tenderness"), "Təngri", "Pillars of Conscience", "Adam and Eve", "Күк iyase" ("The Heavenly Patron"), etc.

They set the horizons of semantic flows, sometimes captured in paintings by uncomplicated means. This is, for example, the work "Omet". 
Its plot, subject, and figurative content seem to be very simple. A boy and an old woman, wearing a national dress and a colorful headscarf fluttering in the wind, stand on the road with their backs to the viewer. The figures are simplified, schematized, and slightly shifted to the left of the center. Consequently, the artist confidently transfers the gaze of the beholder to the main image of the picture - a strange shimmering abyss that opens beyond the line of the not very distant horizon. It vaguely resembles an eye with its irregular ellipsoid shape and a lighted spot in the center - a semblance of an eyeball. Its whitish hue vaguely resembles of a cataract. The visual illusion is enhanced by something like an "eyebrow" - an arc of whitish hue in the left part of the picture behind the figures of the old woman and the boy. The eye also has the semblance of "eyelashes": a simplified image of floral and vegetable ornaments with a slight hint of national Tatar style. It both echoes and contrasts with the colors on the woman's fluttering headscarf, with the ruffles of her dress (they are lighter and more delicate in color than the "eyelashes" of the "eye", i.e. the abyss). Semantic hints at "the local color" are reinforced by barely visible silhouettes of two pointed buildings of the Kazan Kremlin: the Spasskaya Tower and the Syuyumbike Tower. They are part of the abyss, which attracts the eyes of the characters, and part of the horizon, which sets off the remoteness of the abyss in the infinite distance.

In this laconic and relatively simple way, a deep image of a tense dialogue between two people is formed, either with a blind, or just another (not human, only seemingly anthropomorphic) "eye of the sky" i.e. the "eye of existence". It is clear that the boy and the old woman see very different things over the horizon. For a child, this is the future, the hope for a better, brighter life, perhaps connected with Kazan. Its architecture (an allusion to it) is in stark contrast with the muddy road, the wind, and dry reddish wood in the right corner of the picture. The shade of desolation, squalor and lack of comfort is dramatically enhanced by a piece of dry wood with untreated knots, traces of dried branches, sticking out of the frame. Another "splinter", almost symmetrically located, echoes it, its contours are thin, smooth-flowing, as if dried up. It is clear that the intrusion of these wooden details into the canvas of the picture is not accidental. They both mark the death of the living, natural things in the world of a provincial remoteness, and are associated by the artist with the old woman and the boy (one is almost worn out by time, the other still retains traces of life in its knots, in a small split at the end).

All these details and their semantic content impose two distinct symbolic meanings on the image of the alluring abyss beyond the horizon: it is both life and death. In such a semantic horizon, the ornamental "eyelashes" of the abyss, "the eye", also have contrasting shades: for the child it is attractive beauty of nature (or its surrogate), ennobled by human efforts, and for the old woman they appear to be a subtle reminder of the carvings on a tombstone or the fading flowers of her young dreams of another life...

A hint of this semantic shade is the flowers on her shawl and ruffles on her dress. Thus, the artist forms "a tip" that this woman was once attracted to a beautiful dream, and she devoted part of her life to its implementation, decorating her life as much as possible with similar flowers, which had been even brighter and more tender. But it seems she did not find happiness and spiritual harmony, having turned into a strange alien "spot" in the dirtysqualid space of rural and natural existence. But the dream of something beautiful and different, obviously continues to draw her on (her grandson is her successor, her continuation in time). And even the premonition of death did not cool her childish strong desire to go "beyond the horizon" of ordinary and miserable existence.

The image of the boy also has semantic shades of resemblance to his grandmother (gray-white shades in clothing, similarity of poses, the same road under their feet). He might be facing the same fate: his pursuit of the far-off and promising future will only lead to an absurd embellishment of his routine. The circumstances of his existence will not let him fulfill his dream. He is like a dry peg from the picture frame "driven" into the ground, into the road, he does not even take a step forward. It is not accidental, perhaps, that the mentioned fragment of the frame ends with a split that resembles a hand, the movement of its "fingers" seems to be grasping air. And this end of the wooden "splinter" as if sticks into the "eye". This detail has another meaning: a kind of restraining force that resists the alluring dream, wants to "pierce" it like a balloon, alive and "breathing" (an impressionistic manner of layering strokes), unlike the dried-up bush of a tree sticking out of the semblance of earth... Naturally, all these shades of meaning, in such a seemingly "random" detail, occur only in the horizons of symbolic values of the depicted key images. These shades of meaning are hardly rationalized, barely implied, thus forming a certain "aura" of the inex- 
pressible in the picture. The viewer only intuitively recognizes its implicit, but vaguely guessed presence.

A similar process of semantic "fluorescence" is also characteristic of the central images in the picture, especially its key image, the image of the alluring abyss, which is indeterminate for the consciousness of the beholder. In it, as already mentioned, hope and death (attractive as a dream) are united, the deceptions of life and the promise of its beauty and joys are merged. But there are more specific meanings, limited by place and time. Through it, Kazan is opposed to a remote and shelterless province. At this level of associations, the fulfillment of a dream does not look distant and abstract, but seems to be very real, easily achievable not only for the boy, but also for the elderly woman. All these make it possible to imagine the dialogue with Chekhov's "Three Sisters", who dream of a very real, but for some reason unattainable Moscow of their childhood and youth...

However, in addition to these semantic series recognized in culture, the image of the eye-abyss has its own very unusual meaning: it is the gaze of some otherworldly being at man, at his miserable existence. This gaze is mute, indifferent, devoid of any curiosity, almost blind from the antiquity of the creature, but still intent, thinking about something, perhaps questioning... The viewer has a whole swarm of guesses about what kind of creature this might be with such an eye fixed on the two figures, standing before him on the path of life, in its winds. Whether it is life itself with its deceptions and promises, or the eye of God, of the Universe, of some unknowable and indefinable being... Or is it the eye of the sky, the eye of pagan Tengri, as old as humanity itself with its history and prehistoric epochs combined... Even an analogy with the Cosmos is possible in this case, since the sun is visible behind the lighted center, hidden by a veil of clouds. The shades of the cosmos magnify the mysteries of the picture's central image to an unprecedented scale, transferring all the semantic flows into incredible mystical, otherworldly, eternal, incomprehensible to the limited earthly mind environment. The real plot of the picture, its very recognizable characters, and the few details are also drawn into this environment.

It is not by chance that the "eye" looks dual. It is concave, as if attracting the figures with its bright spot and ring-like strokes located around it (the inhuman eye of cosmic depths and otherworldly abysses). At the same time, it looks convex, because its light "eyeball", according to the laws of perception, strives to get to the foreground. It is located almost above the "Kazan". In this illusion of bulging out, one can see a certain anthropomorphism of the otherworldly being, its closely observing effort directed not only at the two figures of the characters, but also at the viewer (due to the size of the "eye"). In this way, the scale of the unknown force embodied in the Central image of the picture is transferred to the real space of human existence, its individual and world history, its human limitations and temporality, values (dreams, hopes), the search for the meaning of existence (in the dreams of the impossible? in the succession of generations? in the eternal confrontation of circumstances and human hopes to overcome them? in the pursuit of the incomprehensible and eternal? in communion with God, the secrets of nature and the universe?..).

The semantic flows of the picture not only go beyond its limits into the horizons of human existence, but also involve the viewer in the artist's reflections on the colossal and ever-disturbing mysteries of existence. To say that this is the scale of philosophical generalizations is to sharply limit them. Philosophy raises its questions with the help of language and is limited by the work of the mind, its human limits. A. Fathutdinov clearly points to the super intelligent, incomprehensible by man, and even more so by philosophical knowledge, horizons. They are guessed only by the viewer's intuition, some kind of pre-rational and even "prehuman" knowledge- flair, for which there are no words in the languages of people... Thus, the eyeabyss becomes the visible embodiment of the inexpressible, incomprehensible, mysterious and superhuman, eternally present in our existence, controlling all its processions and at the same time always only remotely observing from the outside.

These semantic meanings are also implied in the picture. The contour of the "eye" constructs all the lines and the composition as a whole (the lines of ornaments, the fluttering and at the same time static headscarf), and simultaneously shifts the very center of the depicted space, as if breaking its axis, outlined by an almost perfect arch of the upper frame edge. In this simple and very effective way the artist conveys the idea that the presence of an unknown otherworldly force in our existence always brings a certain disharmony, tension in life, pulling on its most important organizing links. In spite of deforming, showing its inexpressible presence, it simultaneously adorns existence, opening in its "gray everyday life" a certain window that adds light to life, as well as an inviting and attrac- 
tive meaning, although unclear, but always implied meaning. In the light of this semantic hue, the people depicted in the picture do not look rejected and abandoned to the "outskirts of life". Someone great, though silent, is always looking at them. Through it, they are connected not just to humanity, but to all being, the Cosmos, the God, and the eternal mysteries of the universe. This is how their human and temporal limitations are overcome, the limitations of their life, mind, knowledge, language, and momentary presence here and now: on a muddy road, in the wind, in the state of abandonment and loneliness.

The "eye" also has a subtle connotation of its connection with Allah. It is outlined in the carving on the frame. In its arched frame at the top, in the right and left corners, there are deliberately crudely carved flowers, similar to a strawberry. On the left, it is just a flower in a recess, on the right, a Crescent moon is attached to the flower, making both details look like the most important attribute of the Muslim religion. Both flowers are deeply set in the wooden frame of the picture, thus forming an association with the "eye", pushed over the horizon, and the ornament of its "eyelashes". On the frame, there are two such similarities to the "eye". And both are deeply set in the natural material. In this way, the frame is also involved in the development of the semantic dynamics of the picture (the artist outlines this possibility).

Obviously, this is how the viewer's involvement in the dialogue with the otherworldly view is strengthened and accentuated, since the characters are inside the picture, and the frame is contemplated by the viewer from the outside. Moreover, there is also a new shade of meaning in this strange "double" of the looking "eye", since it is deeply set in the old, almost decayed wood, and the "eyeballs" of this new hypostasis of the mysterious force do not have such a magnetic force of attraction. Perhaps, the author expressed the idea that the mysterious force, so clearly and powerfully manifested on the canvas, has its refraction in nature, which is also able to look at man forever and silently, attracting him with its natural and recognizable forms. Such "eyes" of nature are mostly "blind", reduced, simplified, and even partially caricatured by their comparison to unpretentious flowers. The Crescent moon in this context is also devoid of its religious meaning and hints only at the connection of natural and celestial gravitations.

The hermeneutical analysis of A. Fathutdinov's painting "Omet" allows us to conclude that the art- ist managed to combine in his small and discreet creation numerous interconnected series of meanings, deep, interesting, captivating the imagination of the viewers, encouraging them not just to empathize, but also to actively think, to manifest intuitive knowledge. By quite simple means, the artist manages to express the most interesting reflections on man's future before the mysterious, sympathetically indifferent universe, and possibly its Creator. Fatkhutdinov managed to create a whole set of hints about the meaning of human existence, its values, the continuity of generations based on these values, the mysterious forms of dialogue between people with otherworldly mystical dimensions that eternally accompany our earthly existence, and even the relationships of the province and the capital...

This dense semantic "cloud" of the picture, which is generated by any, even the most insignificant detail, nuance, lighting solution, composition, and frame design is undoubtedly the evidence of a very high artistic skill. The purpose of all these professional efforts of the artist is to express his own large-scale and original idea of man in his relations with himself, his descendants, with dream and death, with God, and the universe. These are the basic foundations of existence that lie beyond reason, history, or even time. This ability to think so deeply and complicatedly, to direct his inner vision towards the very foundations of life is the special feature of A. Fathutdinov's work that distinguishes him from other artists of his generation. First of all, he is an artist-thinker who has a multidimensional and very broad view of man, nature, the structure of the universe, its mysterious dimensions that cannot be rationally analyzed.

Naturally, this is still only a hypothesis, since the analysis of the picture alone does not make it possible to confirm our conclusion with a high degree of confidence. But this research enables us to outline the main ways to the further study of A. Fathutdinov's creations, his creative originality. In our opinion, the hermeneutical approach will be the most effective on this path, as it is based on a systemic view of a painting or sculpture as a complexly organized whole (organized by the artist), in which there is nothing accidental or unimportant.

The hermeneutical method of analysis can be supplemented by building a dialogue with the philosophical trends of the twentieth century, especially with existentialism. It is this similarity that sets up the analysis of semantic structures of the painting "Omet". The most prominent representatives of this trend, such as S. Kierkegaard [Kierkegaard, 
1844], M. Heidegger [Heidegger, 1927], J.-P. Sartre [Sartre, 1943], and others considered intuitive ways of recognizing the deep secrets of being and human existence to be a priority. It is the existentialists who have blurred the boundaries between the individual and the spaces of its presence in the world, its relationships with the divine principle, the main focus of their studies. They declared the tremendous importance of such states as the premonition of death, the unquenchable fear, and the silent reproaches of conscience, which enable the individual to experience and realize the temporality and finality of existence in a boundless and eternal being. It is their idea of a silent "call of being" addressed to man...

In the picture "Omet", we hear the echoes of this philosophical problem. Its ways of getting into the painting is another scientific issue that requires an in-depth study, based on the artist's biographical information, his epistolary heritage, and reviews from his contemporaries.

However, when making parallels with existentialist ideas, one should not get too carried away, we should always keep in mind the possibility of parallel spiritual searches and discoveries in culture. This thesis should be taken into account when dealing with the artistic understanding of the world, which often precedes rational scientific formulations of knowledge, and often paves the way for their emergence in culture. In this connection, it is worth recalling Russian literature of the 19th century with its colossal philosophical potential, the works of the representatives of the absurd in literature, the innovations of the painters of the late 19th and early 20th centuries, etc. Therefore, in drawing analogies with the philosophy of existentialism, we see only one of the ways of relative rationalization, the scientific understanding of the subject-matter of A. Fathutdinov's works, which is difficult to comprehend and express by the scientific consciousness in the field of meanings. Previously, it was defined as "inexpressible", not fully comprehensible and hardly worded. In this sense, existentialism looks like a conceptual and verbal "arsenal" that will allow us to understand and describe (although not very accurately) the semantic horizons to which the creative intuition of A. Fathutdinov is directed, which has formed in many ways his special personality, its unique face.

The scale of this personality is all the more striking when you get acquainted with the artist's biography. One can hardly find any prerequisites for the formation of such a significant creative figure. This story of a provincial artist's life is quite typical for the Soviet era and the period of perestroika. Everything in this life, it would seem, should have shaped the way of thinking, characterizing a marginal person, oriented by birth, education, and environment to create works in the spirit of socialist realism with connotations of the Tatar culture national color.

Akhsan Sarimovich Fathutdinov was born in 1939 in the village of Podlesny Utyamysh in the Cheremshan district of the Tatar ASSR. He studied at the Pedagogical College, first in Kamyshin, then in Buguruslan (graduated in 1957). He served in the army, then, he graduated from the Art and Graphic Faculty of the Nizhny Tagil Pedagogical Institute. Later, he worked as a teacher at the same Institute for several years. From 1969, he lived in Nizhnekamsk, where he worked at the art and production site. He got the status of a professional artist only in 1984 and continued to work hard and fruitfully.

His works still adorn buildings and interiors in Nizhnekamsk: the Music College, the Power Engineering College, the airport, the hotel "Kama", the cafe "Ekiyat", the amusement park. The city gratefully honors the memory of its citizen. He was awarded the title "The Honorary Citizen of Nizhnekamsk" for the services to the city and its residents, for fruitful educational work. But most importantly, there is an exhibition hall, which displays quite a number of works by A. Fatkhutdinov.

However, provincial existence did not become an obstacle to a fairly wide recognition of his creative success, both in Tatarstan and beyond. He took an active part in exhibitions, not only in the Volga region, but also in Moscow, St. Petersburg, Istanbul, and Budapest. Some of his works are in museums in Russia, in private foreign galleries, in the National-Cultural Center of Kazan.

One of A. Fathutdinov's favorite genres was the cycle of paintings. Obviously, it allowed him to convey to the viewer a multi-faceted and complex vision of the subject in his paintings. His series, dedicated to Tukay and the images of his creations, numbers more than a hundred works, and the cycle "Shurale" - more than fifty. A. Fatkhutdinov also executed the cycles "A Tatar Cemetery", "Amulets", "Amulets in the Moonlit Night", "Bullied". The artist painted landscapes, portraits, and everyday scenes from village life.

His paintings are mostly created in a primitive manner. They have attributes of Sots art, which enhance the illusion of simplicity and laconism of artistic expression. This manner corresponds well to unpretentious subjects, adding deliberate rough- 
ness to the depicted objects: rural landscapes, faces, and details of everyday life. Often the artist turned to pagan, biblical, pre-Muslim times, which, apparently, contribute to their interpretation in a primitive manner and generate a dialogue with African and Indian cultures, with Tatar folklore. The simplicity and "naivety" of their figurative and expressive systems enabled the artist to look into sources of human existence, to search for the root causes of human existence, its correlation with the worlds of nature, gods, and mystical dimensions.

The above said can be equally applied to the sculptural works of A. Fathutdinov. They have the same striving to see reality in its primeval forms, untouched by any tricks of culture. The choice of wood as the main material, obviously, made it possible for the artist to collaborate with nature itself as his co-creator, to execute his works based on her clues and his own intuition, which would be akin to an ancient man who could see a face or a figure of a deity, a human face or the contours of an animal in the wood texture. The sculptor's chisel with only a minimum of strokes and accents brings the implicit natural creation to the surfaces of the wood, so that it could be clearly defined in its inflections, knots, lines, fractures and other deformations.

All these searches for vivid and organic means of expression for the created images corresponded to the spirit of the pre-perestroika and perestroika times. The plastic languages of Soviet art were actively renovated, often using the discoveries of Western European modernism and Russian avantgarde. These processes took place not only in the capitals (Moscow and St. Petersburg), but also in provincial art, as evidenced, for example, by the monograph of R. Sultanova on the work of artists from the "new cities" of Tatarstan. For Russia, these were fairly recent trends. They ensured the interest of the audience and high ratings among art critics. Largely due to this, the work of A. Fathutdinov received recognition, partially voiding it of the status of a provincial artist's work. The pinnacle of recognition was the awarding of the Tatarstan State Prize named after G. Tukay in 1993 for his series of works based on the national epic "Iyalar" ("The Amulets").

The works of A. Fathutdinov have always aroused the interest not only of art historians, but also of journalists and scientists. This is evidenced by numerous publications in the periodical press of Tatarstan ("Tugan Yak", "Nizhnekamskaya Pravda", "Madani Jomga", "Kazan Utlary", "Vatanym Tatarstan", "Tatar Ile", "Soembike", "Izvestiya
Tatarstan", etc.). They published vivid impressions of the artist's exhibitions, his interviews, interesting reflections on his cycles, individual works, facts from his biography, observations on the features of his manner of painting, and reflections on the national features, characterizing his works. All these publications are clear evidence of the viewers' interest in his images and ideas embodied in the works of a very talented person.

However, in my opinion, the primary interest of art historians in the "national issues" of A. Fathutdinov's works, or in his artistic and plastic language, has greatly limited, narrowed the real range of work that characterizes his paintings. It impedes the understanding of the true scale and uniqueness of his oeuvre. Therefore, it is necessary to search for new approaches and develop research strategies that would enable the subject of the study itself to profoundly and adequately disclose its most essential features.

This article is merely a first and so far cautious step in this direction. Its main purpose is not to "characterize the work" of A. Fathutdinov, or to identify certain universal features in his works. It is necessary to delve into the world of meanings and problems that worried the author, based on his "Omet" painting, in order to outline only the first touch in a new approach to the study of his original and very large-scale thinking, which makes the center of the artistic worlds of any creator.

\section{References}

Chervonnaia, S. M. (1974). Hudozhniki Tatarii. [The Artists of Tartary]. 75 p. Kazan', Tat. kn. izd-vo. (In Russian)

Fainberg, A. B. (1983). Hudozhniki Tatarstana. The Artists of Tatarstan]. 232 p. Leningrad, Hudozhnik RSFSR. (In Russian)

Haidegger, M. (1997). Bytie i vremya. [Being and Time]. 452 p. Moscow, Ad Marginem. (In Russian)

Kierkegaard, S. (2009). Filosofskie krohi, ili krupitsy mudrosti [Philosophical Crumbs, or Grains of Wisdom]. Per. D. A. Lunginoi. 192 p. Moscow, Institut filosofii, teologii i istorii sv. Fomy. (In Russian)

Nigmatullina, Yu. G. (2002). "Zapozdalyi modernizm" $v$ tatarskoi literature $i$ izobrazitel'nom iskusstve. ["Belated Modernism" in Tatar Literature and Fine Arts]. 175 p. Kazan, Fen. (In Russian)

Nigmatullina, Yu. G. (2011). Tatavangard $i$ sovremennyi tsivilizatsionnyi protsess. [Tatar Avantgarde and Modern Civilizational Process]. 68 p. Kazan, Fən. (In Russian)

Nigmatullina, Yu. G. (2014). Tatavangard kak element sredinnoi kul'tury [Tatar Avant-garde as an Element of "Middle Culture"]. Tatarica, No. 1 (2), pp. 156-178. (In Russian) 
Nigmatullina, Yu. G. (2015). Tatavangard: nacional'nye hudozhestvennye tradicii kak integrativnyj faktor $v$ dialoge razlichnyh stilej [Tatar Avant-garde: National Artistic Traditions as an Integrative Factor in the Dialogue of Various Styles]. Tatarica, No. 2 (5), pp. 165-188. (In Russian)

Sartr, Zh.-P. (2000). Bytie $i$ nichto: Opyt fenomenologicheskoi ontologii [Being and Nothingness: The Experience of Phenomenological Ontology]. Per. s fr., predisl., primech. V. I. Kolyadko. 640 p. Moscow, Respublika. (In Russian)

Sultanova, R. R. (2001). Iskusstvo novyh gorodov Respubliki Tatarstan (1960-1990 gg.). Zhivopis', grafika, monumental'no-dekorativnoe iskusstvo, skul'ptura. [Art of New Cities of the Republic of Tatarstan (1960-1990). Painting, Drawing, Monumental and Decorative Art, Sculpture]. 192 p. Kazan [b. i.]. (In Russian)

Shageeva, R. G. (2002). Ahsan Fathutdinov. [Ahsan Fathutdinov]. 220 p. Kazan, Ruhiyat. (In Russian)

Valeev, V. H. (1984). Narodnoe dekorativnoe iskusstvo Tatarii. [Folk Decorative Art of Tartary]. 149 p. Kazan, Tatar. kn. izd-vo. (In Russian)

Valeeva, D. (2015). Misticheskii mir Ahsana Fathutdinova [The Mystical World of Ahsan Fathutdinov]. Kazanskii al'manah. No. 15, pp. 156-160. (In Russian)

Valeeva-Suleimanova, G. F. (1984). Monumental'no-dekorativnoe iskusstvo Sovetskoj Tatarii [Monumental and Decorative Art of Soviet Tartary]. 120 p. Kazan, Tatar. kn. izd-vo. (In Russian)

\title{
А. ФАТХУТДИНОВ В СОЗЕРЦАНИИ ЗАГАДОК МИРОЗДАНИЯ (ОПЫТ ГЕРМЕНЕВТИЧЕСКОГО АНАЛИЗА КАРТИНЫ «ӨМЕТ» («НАДЕЖДА»))
}

\author{
Светлана Викторовна Синцова, \\ Россия, 420066, Казань, ул. Чистопольская, д. 7, кв. 19, \\ esintsov@mail.ru.
}

\begin{abstract}
В статье предпринята попытка наметить новый подход к определению оригинальных черт живописных произведений Асхана Фатхутдинова: исследование системы смыслов его творений. Необходимость и продуктивность такого герменевтического подхода обосновывается благодаря углубленному изучению картины «Өмет» («Надежда»).

Комплексный анализ тематики, образной системы, выразительно-изобразительных средств, возможных реакций реципиента позволил сделать вывод о сложнейшей, философски и мистически ориентированной системе смыслов, передающих глубокий и динамичный мир оригинальных представлений художника о смысле человеческого существования, его ценностях, о преемственности поколений на основе таких ценностей, о таинственных формах диалога людей с потусторонними, мистическими измерениями, извечно сопровождающими земное существование, и даже об отношениях провинции и столицы.

Такого рода наблюдения позволили не только провести параллели художественных открытий А. Фатхутдинова с идеями философов-экзистенциалистов, но и установить границы таких возможных аналогий.

В статье также изложены основные факты биографии А. Фатхутдинова и отмечены наиболее характерные черты его художественной манеры.
\end{abstract}

Ключевые слова: живопись, Асхан Фатхутдинов, картина «Өмет» («Надежда»), герменевтический анализ, комплексный метод, экзистенциализм, мистицизм, бытие, Аллах, Тенгри.

Произведения А. Фатхутдинова - и притягательный и в то же время сложный предмет для научного анализа. На первый взгляд, они просты и даже незатейливы. Этот обманчивый облик создают едва обработанные куски дерева, растрескавшегося, старого, которое в быту отправили бы, скорее всего, в печку. А художник, чуть подправив, очистив от коры, использовал для скульптур, панно, для странных рам, обрамляющих картины или вторгающихся в живописное полотно. И живопись его под стать скульптуре: без изысков и затей, в манере модного в недалеком прошлом примитива. Тематика произведений тоже не поражает новаторством и изысканным выбором: языческие образы духов, божков, библейские мотивы (Адам и Ева, трансформированный крест для распятия), детали и сцены деревенского быта. Неяркая палитра лишь усиливает ощущение простоты, естественности, непритязательности. Краски как 
бы вторят оттенкам и фактуре дерева, которым обрамлены картины. Так создан любопытный эффект, не раз подмеченный искусствоведами: окна, из которых сельский житель что-то пристально разглядывает или случайно краем глаза увидел, неожиданно подсмотрел.

Искусствоведу, приступающему к анализу этих творений, особо и зацепиться не за что. По живописной манере все узнаваемо и вторично в контексте мировых художественных течений и направлений: «запоздалый модернизм», как определила эту особенность живописи Татарстана Ю. Г. Нигматуллина в названии своей монографии [Нигматуллина, 2002], примитив и соц-арт - Р. Р. Султанова [Султанова, с. 59]. Органично вписанным в основные течения изобразительного искусства предстает А. Фатхутдинов и в исследованиях С. М. Червонной (1974) [Червонная], В. Х. Валеева (1984) [Валеев, с. 149], Г. Ф. Валеевой-Сулеймановой (1984) [Валеева-Сулейманова], А. Б. Файнберга (1983) [Файнберг].

Необычно в контексте художественных тенденций и творческих исканий художников Татарстана ([Нигматуллина, 2011], [Нигматуллина, 2014], [Нигматуллина, 2015], [Султанова], [Червонная] и др.) выглядит лишь цикл «Ияләр» («Обереги»), в котором представлены очеловеченные образы духов [Валеева].

Именно их анализу уделяет пристальное внимание Р. Г. Шагеева в статье, предваряющей альбом работ А. Фатхутдинова (2002) [Шагеева, с. 5-13]. Ее вступительная статья к изданию репродукций художника (2002) во многом обобщает основные наблюдения искусствоведов и их попытки определить наиболее характерные черты его творчества.

Из основных особенностей наследия живописца и скульптора отмечены «светлая печаль» как общий эмоциональный тон, общечеловеческий план творений, тяготение к философичности, космизму, «литературности», подчеркнут национальный колорит образов (фольклорные, мифологические образы, «вся система татарской культуры»). Отмечен диалог культур (в основном с «древними цивилизациями»). Определен основной конфликт творений художника (человек и природа), выявлены некоторые особенности художественного языка (символика цвета, техники резьбы и письма, решение рам). Таким образом, Р. Г. Шагеевой удалось наметить целый ряд аспектов исследования. Ее статью можно рассматривать как развернутый проспект монографии.

Предпринимая такое комплексное рассмотрение творчества А. Фатхутдинова, искусствовед стремится оттенить и подчеркнуть оригинальность его работ, что, несомненно, соответствует задачам вступительной статьи к изданию репродукций. Но из перечисленных и отмеченных ею особенностей оттенки неповторимости свойственны, пожалуй, только разнообразным фольклорно-мифологическим персонажам, к изображению которых столь часто обращался этот художник, а также огромной роли деталей из дерева, которыми он дополнял изображения на картинах. Косвенным доказательством этому служит обширный материал, представленный в упомянутой выше монографии Р. Р. Султановой [Султанова]. Почти все черты творчества А. Фатхутдинова, намеченные Р. Г. Шагеевой, можно найти в творениях его современников из «новых городов» Татарстана: диалог культур, конфликт человека и природы, космизм, литературность, образы татарского фольклора, эксперименты с художественной выразительностью и др.

В свете таких традиционных научных подходов творчество А. Фатхутдинова не выглядит слишком оригинальным, заметным, легко укладывается в прокрустово ложе искусствоведческих клише, создающих образ маргинального, хоть и не без интересных находок, художника, вписывающегося в контекст творческих исканий «художников новых городов Республики Татарстан». Многие из них тоже искали различные приемы и способы соединить с «запоздало-модернистскими» новациями элементы национального искусства, предчувствия социально-духовных перемен в обществе, открытие новых тем в живописи и скульптуре. И делали это ярко, оригинально и достойно, достигая высокого уровня мастерства, художественной выразительности и масштабной глубины смыслов.

А. Фатхутдинов, несомненно, принадлежит к их числу, стоит в этом ряду, но и странным образом выбивается из него. Есть у этого скульптора и живописца что-то неповторимое, уникальное, что придает его творческому облику «лица не общее выражение».

Эта аура его творений невольно ощущается в неспешном и вдумчивом созерцании. Картины не просто притягивают взгляд, они побуждают к долгому и пристальному разглядыванию. Они приглашают в неведомые миры, представляют зрителю невиданных существ, 
странно трансформированные лица и фигуры людей, образы животных, птиц, деталей быта. За этими трансформациями, искажениями угадывается не только буйство фантазии художника и скульптора, но и тихое, хоть и страстное, желание о чем-то поведать зрителю, поделиться с ним своим тайным знанием о жизни, о богах, о сказочных и мистических измерениях. Рамы картин как бы приглашают подойти ближе и пристально вглядеться в то, что в обычной жизни незримо, но, может быть, тайно присутствует в неведомых измерениях бытия.

А. Фатхутдинов пытается пробудить не просто любопытство, сродни детскому, но активизировать интуицию зрителя, его дорациональное знание, наследованное из древних эпох. Художник умело создает условия для углубленного многомерного диалога со зрителем, которому позволяется погрузиться в образы и миры автора, почувствовать и угадать затаенный ток его мыслей и состояний. И тогда перед удивленным внимательным созерцателем открывается почти безбрежный горизонт сложных и напряженных стремлений автора угадать и выразить какое-то глубинное знание о мире, человеке, Боге, иномирных существах и обитаемых таинственных пространствах. За кажущейся простотой и незатейливостью сюжета, неяркостью палитры проступает сложнейшая динамика смыслов, свойственная лишь высоким художественным созданиям человеческого духа. Переплетение смыслов достигает порой масштабных обобщений, приближаясь к осмыслению извечных тайн бытия, к философскому (но никогда не к рационалистическому) их постижению.

К погружению в эти сложные и многомерные горизонты смыслов приглашают порой уже названия: «Молодость. Старость», «Наз» («Нежность»), «Тәнгри» («Тенгри»), «Столпы совести», «Адам и Ева», «Күк иясе» («Небесный покровитель») и др.

Они задают горизонты смысловых потоков, запечатленных в картинах порой незамысловатыми средствами. Такова, к примеру, работа «Өмет».

Ее сюжет, тематика, образное наполнение кажутся очень простыми. Мальчик и старуха в национальном платье и цветастом развевающемся на ветру платке стоят на дороге спиной к зрителю. Фигуры упрощенные, схематизированные, чуть смещены влево от центра. Так взгляд смотрящего уверенно переносится художником на главный образ картины - стран- ную мерцающую бездну, что открывается за линией не очень далекого горизонта. Она отдаленно напоминает глаз своей неправильной эллипсоидной формой и высветленным пятном в центре - подобием зрачка. Своим белесоватым оттенком он отдаленно напоминает бельмо. Иллюзию глаза усиливает нечто вроде «брови» - дуги беловатого оттенка в левой части картины, за фигурами старухи и мальчика. Есть у глаза и подобие «ресниц»: упрощенное изображение цветочно-растительного орнамента с легким намеком на национальный татарский. Он перекликается и контрастирует с цветами на развевающемся платке женщины, с оборками ее платья (они светлее и нежнее по колориту, нежели «ресницы» «глаза»-бездны). Смысловые намеки на «местный колорит» усилены едва видимыми силуэтами двух остроконечных построек Казанского кремля: Спасской башни и башни Сююмбике. Они и часть бездны, приковывающей взгляд персонажей, и часть горизонта, что оттеняет отодвинутость бездны в бесконечную даль.

Так лаконично и относительно просто сформирован глубокий образ напряженного диалога двух людей с то ли слепым, то ли просто иным (не человеческим, только кажущимся антропоморфным) «оком неба», «глазом бытия». Ясно, что мальчик и старая женщина видят за горизонтом совершенно разное. Для ребенка это будущее, надежда на лучшую, более светлую жизнь, связанную, возможно, с Казанью. Ее архитектура (намек на нее) резко контрастирует с грязной дорогой, ветром, сухим красноватым деревом в правом углу картины. Резко усилен оттенок запустения, убожества и неуюта торчащим из рамы куском сухой деревяшки с необработанными сучками - следами засохших веток. Вторит ей почти симметрично расположенная другая «щепка», контуры которой тонкие, гладко-текучие, как бы иссохшие. Ясно, что вторжение этих деревянных деталей в полотно картины не случайно. Они не только обозначают умирание живого, природного в мирке провинциального захолустья, но и ассоциированы художником со старухой и мальчиком (одна почти стесана временем, другая еще хранит следы жизни в сучках, в небольшом расщепе на конце).

Все эти детали, их смысловое наполнение накладывают на образ манящей бездны за горизонтом два отчетливых символических значения: это и жизнь, и смерть. В таком смысловом горизонте у орнаментально подобных «ресниц» 
бездны-«глаза» также намечаются противоположные оттенки: влекущей красоты, облагороженной человеческими усилиями природы (или ее суррогата) для ребенка, а для старухи они же предстают как едва уловимое напоминание о резьбе на могильной плите или как засыхающие цветы ее юных мечтаний об иной жизни...

Намек на этот смысловой оттенок - цветы на ее платке, оборки на платье. Так художником сформирована «подсказка», что женщину тоже когда-то влекла красивая мечта, и она отчасти свою жизнь посвятила ее воплощению, украсив по мере сил свою жизнь похожими цветами, даже более яркими и нежными. Но счастья и душевной гармонии, похоже, так и не обрела, став лишь странным чужеродным «пятном» в грязно-убогом пространстве деревенского и природного существования. Но мечта о красивом и ином продолжает, очевидно, манить и еe (внук - ее преемник, продолжение во времени). И даже предвестие смерти не остудило ее по-детски сильного влечения «за горизонт» обыденного и убогого существования.

У образа мальчика также есть смысловые оттенки уподобления бабушке (серо-белые оттенки в одежде, сходство поз, одна дорога под ногами). Его, возможно, ждет повторение ее судьбы: стремление к далекому и многообещающему приведет лишь к нелепому приукрашиванию своей обыденности. Обстоятельства его существования не позволят осуществить мечту. Он, как сухой колышек из рамы картины, «вбит» в землю, в дорогу, не делает даже и шага вперед. Не случайно, наверное, упомянутый фрагмент рамы завершен расщепом, напоминающим кисть руки, движение «пальцев» которой напоминает хватание воздуха. И этим своим завершением деревянная «щепка» как бы втыкается в «глаз». Так у данной детали возникает еще одно значение: некоей удерживающей силы, противостоящей манящей мечте, желающей ее «проткнуть» как воздушный шарик, живой и «дыщащий» (импрессионистическая манера наслаивающихся мазков), в отличие от высохшего куска дерева, торчащего из подобия земли... Естественно, все эти оттенки значений у такой, казалось бы, «случайной» детали возникают только в горизонтах символических значений ключевых образов картины. Эти оттенки смыслов с трудом рационализируются, едва угадываются, составляя некую «ауру» невыразимого картины. Зритель лишь интуитивно опознает ее неявное, но смутно угадываемое присутствие.
Но сходный процесс смыслового «флюоресцирования» характерен и для центральных образов картины, особенно ключевого для нее и неопределенного для сознания смотрящего образа манящей бездны. В ней, как уже упоминалось, соединяются надежда и смерть (притягательная, как мечта), слиты обманы жизни и обещание ее красот, радостей. Но есть и более конкретные значения, ограниченные местом и временем. Так, через нее Казань противопоставлена глубокой и бесприютной провинции. На этом уровне ассоциаций достижимость мечты выглядит не далекой и абстрактной, а очень реальной, легко осуществимой не только для мальчика, но и для пожилой женщины. Так становится возможным едва угадываемый диалог с чеховскими «Тремя сестрами», мечтающими о вполне реальной, но почему-то недостижимой Москве их детства и юности...

Но у образа глаза-бездны есть, помимо этих укорененных в культуре смысловых рядов, и весьма необычный: это взгляд какого-то иномирного существа на человека, на его убогое существование. Взгляд немой, равнодушный, лишенный всякого любопытства, почти слепой от древности существа, но все еще пристальный, о чем-то размышляющий, может быть, вопрошающий... У зрителя рождается целый рой догадок о том, что это за существо с подобным оком, вперенным в две фигуры, предстоящие перед ним на дороге жизни, на ее ветрах. То ли это сама жизнь с ее обманами и обещаниями, то ли глаз Бога, мироздания, некоего непознаваемого и неопределимого бытия... Или это око неба, око языческого Тенгре, древнего, как само человечество с его историей и доисторическими эпохами вместе взятыми... Даже аналогия с космосом в этом случае возможна, поскольку за высветленным центром угадывается солнце, скрытое пеленой облаков. Оттенки космического придают тайнам центрального образа картины невиданный масштаб, переводя все смысловые потоки в невероятные плоскости мистического, потустороннего, вечного, непостижимого ограниченным земным разумом. В эти плоскости оказывается втянутым и вполне реальный сюжет картины, его очень узнаваемые персонажи, немногочисленные детали.

Не случайно «глаз» предстает двояким. Он и вогнутый, как бы притягивающий фигуры своим светлым пятном и кольцеобразно расположенными вокруг него мазками (нечеловеческий глаз космических глубин и иномирных 
бездн), но одновременно он выглядит и выпуклым, поскольку его светлый «зрачок» по законам восприятия стремится на передние планы. Он расположен почти над «Казанью». В такой иллюзии выпуклости угадывается некая антропоморфность потустороннего существа, его пристально наблюдающее усилие, направленное не только на две фигурки персонажей, но и на зрителя (благодаря величине «глаза»). Так масштаб неведомой силы, воплощенной в центральном образе картины, переносится на реальные пространства человеческого существования, его индивидуальную и мировую историю, его человеческую ограниченность и временность, ценности (мечты, надежды), поиски смысла существования (в мечтах о несбыточном? в преемственности поколений? в вечном противостоянии обстоятельств и человеческих надежд на их преодоление? в стремлении к непостижимому и вечному? в приобщении к Богу, тайнам природы и мироздания?..).

Смысловые потоки картины не только выходят за ее пределы в горизонты человеческого существования, но и вовлекают зрителя в размышления художника о колоссальных и вечно тревожащих загадках бытия. Сказать, что это масштабы философских обобщений, значит резко обузить их. Философия ставит свои вопросы с помощью языка и ограничена работой разума, его человеческими пределами. А. Фатхутдинов отчетливо указывает на сверхразумные, непостижимые человеком, а тем более философским знанием, горизонты. Они угадываются лишь интуицией зрителя, неким его дорациональным и даже «дочеловеческим» знанием-чутьем, для которого и слов-то в языках людей нет... Так бездна-глаз становится зримым воплощением невыразимого, непостижимого, таинственного и надчеловеческого, вечно присутствующего в нашем существовании, управляющего всеми его процессами и в то же время всегда лишь отстраненно наблюдающего со стороны.

Эти смысловые значения также угадываются в картине. Контур «глаза» выстраивает все линии и композицию в целом (линии орнаментов, развевающегося и в то же время статичного платка) и одновременно смещает самый центр изображенного пространства, как бы ломая его ось, намеченную почти идеальной аркой верхнего края рамы. Так просто и очень эффективно передана идея о том, что присутствие неведомой иномирной силы в нашем существовании всегда привносит некую дисгармо- нию, напряжение в жизнь, перетягивая на себя ее важнейшие организующие связи, но, деформируя, являя свое невыразимое присутствие, она одновременно украшает существование, открывая в его «серых буднях» некое окно, придающее жизни свет, манящий и притягательный смысл, хоть и неясное, но всегда угадываемое значение. В свете такого смыслового оттенка люди, изображенные на картине, не выглядят отвергнутыми и заброшенными на «окраину жизни». Некто великий, хоть и безмолвный, всегда взирает на них. Через него они приобщены не просто к человечеству, но всему бытию, космосу, Богу, извечным тайнам мироздания. Так преодолевается их человеческая и временная ограниченность, ограниченность их жизни, разума, знаний, языка, сиюминутного присутствия здесь и сейчас: на грязной дороге, на ветру, в состоянии заброшенности и одиночества.

Есть у «ока» и едва уловимый оттенок связи с Аллахом. Он намечен в резьбе на раме. В его арочном обрамлении сверху в правом и левом углу есть нарочито грубо вырезанные цветы, похожие на земляничные. Слева это просто цветок в углублении, справа к цветку примыкает полумесяц, превращая обе детали в подобие важнейшего атрибута мусульманской религии. Оба цветка глубоко утоплены в дереве рамы, выстраивая тем самым ассоциацию с «глазом» на картине, отодвинутом за горизонт, и орнаментом его «ресниц». Причем на раме оказываются два таких подобия «глазу». И оба погружены в естественно-природный материал. Так рама оказывается также вовлеченной в развитие смысловой динамики картины (художник намечает такую возможность).

Очевидно, таким образом усилена и акцентирована вовлеченность зрителя в диалог с потусторонним взглядом, поскольку персонажи находятся внутри картины, а раму созерцает смотрящий со стороны. Но есть и новый оттенок значения у этого странного «дублера» смотрящего «ока», поскольку оно погружено в старое, почти обветшавшее дерево, а «зрачки» этой новой ипостаси таинственной силы не обладают такой магнетической силой притяжения. Так, возможно, автор выразил мысль о том, что таинственная сила, столь явно и мощно явленная на полотне, имеет свое преломление в природе, которая также способна вечно и безмолвно взирать на человека, привлекая его своими естественными и узнаваемыми формами. Такие «глаза» природы в большей мере 
«слепы», уменьшены, опрощены и даже отчасти шаржированы уподоблением простеньким цветам. Полумесяц в таком контексте тоже лишается религиозного смысла и намекает лишь на связь природного притяжения с небесным.

Проведенный герменевтический анализ картины А. Фатхутдинова «Өмет» позволяет сделать вывод, что художнику удалось соединить в своем небольшом и неярком творении многочисленные взаимосвязанные ряды смыслов, глубоких, интересных, увлекающих воображение зрителя, побуждающих его не просто к сопереживанию, но и к активной работе мысли, интуитивного знания. Довольно простыми средствами художнику удалось выразить интереснейшие размышления о предстоянии человека перед загадочным, участливо-равнодушным мирозданием, а возможно, и его создателем. А. Фатхутдинову удается создать целую совокупность намеков на представление о смысле человеческого существования, его ценностях, о преемственности поколений на основе таких ценностей, о таинственных формах диалога людей с потусторонними мистическими измерениями, извечно сопровождающими земное существование, и даже об отношениях провинции и столицы...

Такое плотное смысловое «облако» картины, на порождение которого работает любая, даже самая незначительная, казалось бы, деталь, нюанс, световое решение, композиция, оформление рамы, - несомненное свидетельство очень высокого художественного мастерства. И цель всех этих профессиональных усилий художника - выразить свое собственное масштабное и оригинальное представление о человеке в его отношениях с самим собой, своими потомками, с мечтой и смертью, с Богом, мирозданием. Это исходные основы существования, лежащие за пределами разума, истории и даже времени. Именно в умении так глубоко и сложно мыслить, устремляться внутренним взором к самым первоосновам бытия видится та особая черта творчества А. Фатхутдинова, которая отличает его от других художников его поколения. Он в первую очередь художникмыслитель, обладающий многомерным и очень широким взглядом на человека, природу, устройство мироздания, его таинственные измерения, не поддающиеся рациональному анализу.

Естественно, это пока лишь гипотеза, поскольку анализ одной лишь картины не дает возможности с высокой степенью достоверности подтвердить только что полученный вывод.
Но проведенное исследование позволяет наметить основные пути дальнейшего изучения созданий А. Фатхутдинова, его творческой оригинальности. На наш взгляд, наиболее эффективным на этом пути будет герменевтический подход, опирающийся на системное представление о живописном произведении или скульптуре как сложноорганизованном целом (организованном художником), в котором нет ничего случайного, маловажного.

Дополнить герменевтический способ анализа может выстраивание диалога с философскими течениями XX века, особенно с экзистенциализмом. Именно на такое сходство настраивает анализ смысловых конструкций «Өмет». Крупнейшие представители этого направления, такие как С. Кьеркегор [Кьеркегор], М. Хайдеггер [Хайдеггер], Ж.-П. Сартр [Сартр] и др., считали приоритетным интуитивные способы опознавания глубинных тайн бытия и человеческого существования. Именно экзистенциалисты поставили во главу угла своих штудий стирание границ между личностью и пространствами ее присутствия в мире, ее отношений с божественным началом. Они заявили о колоссальной важности таких состояний, как предчувствие смерти, неизбывный страх, молчаливые укоры совести, позволяющие индивиду пережить и осознать временность и конечность существования в безграничном и вечном бытии. Им же принадлежит идея о безмолвном «зове бытия», обращенного к человеку...

В картине «Өмет» отголоски этой философской проблематики, несомненно, присутствуют. Как она проникла в живописное полотно - еще одна из научных проблем, требующих углубленного изучения на основе биографических сведений о художнике, его эпистолярного наследия, сбора отзывов современников.

Но на пути выстраивания аналогий с экзистенциалистскими идеями не нужно сильно увлекаться, следует всегда помнить о возможности параллельных духовных исканий и открытий в культуре. Особенно это важно учитывать, имея дело с художественным постижением мира, которое нередко предшествует рациональным научным формулировкам знаний, часто подготавливает их возникновение в культуре. Достаточно в этой связи напомнить о русской литературе XIX века с ее колоссальным философским потенциалом, о творениях представителей литературы абсурда, о новациях живописцев конца XIX - начала XX века и др. Поэтому в привлечении аналогий с философией 
экзистенциализма нам видится лишь один из способов относительной рационализации, научного осмысления той проблематики творчества А. Фатхутдинова, которая составляет с трудом постигаемую и выражаемую научным сознанием область смыслов. Ранее она была определена как «невыразимое», до конца не постигаемое и словом не сказуемое. Экзистенциализм и выглядит в таком плане как понятийнословесный «арсенал», который позволит понимать и описывать (хотя и приблизительно) те смысловые горизонты, к которым была устремлена творческая интуиция А. Фатхутдинова, сформировавшая во многом его особенную личность, ее уникальное лицо.

Масштаб этой личности тем более поражает, когда знакомишься с биографией художника. В ней невозможно увидеть никаких предпосылок для формирования столь значительной творческой фигуры. Это довольно типичная для советской эпохи и периода перестройки история жизни провинциального художника. Все в этой жизни, казалось бы, должно было сформировать мышление маргинала, ориентированного и рождением, и образованием, и окружением на создание произведений в духе социалистического реализма с признаками национального колорита татарской культуры.

Родился Ахсан Саримович Фатхутдинов в 1939 году в деревне Подлесный Утямыш Черемшанского района Татарской ССР. Учился в педагогическом училище, сначала в Камышине, потом в Бугуруслане (окончил в 1957 году). Служил в армии, потом закончил художественно-графический факультет Нижнетагильского педагогического института. Потом несколько лет работал в том же институте преподавателем. С 1969 года жил в Нижнекамске, где работал на художественно-производственном участке. Статус профессионального художника получил лишь в 1984 году. Много и плодотворно трудился.

Его работы по сей день украшают здания и интерьеры в Нижнекамске: музыкальное училище, энергостроительный техникум, аэропорт, гостиница «Кама», кафе «Экият», парк аттракционов. Город с благодарностью чтит память земляка. За заслуги перед городом и его жителями, за плодотворную воспитательную работу ему было присвоено звание «Почетный гражданин Нижнекамска». Но самое главное, там есть выставочный зал, в котором представлены довольно многочисленные работы А. Фатхутдинова.
Но провинциальное существование не стало преградой для довольно широкого признания творческих успехов художника как в Татарстане, так и за его пределами. Он принимал активное участие в выставках, причем не только в Приволжском регионе, но и в Москве, СанктПетербурге, Стамбуле, Будапеште. Часть его творений есть в музеях России, в частных зарубежных галереях, в Культурном центре г. Казани.

Одним из любимых жанров А. Фатхутдинова был цикл. Очевидно, он позволял передавать зрителю многогранное и сложное видение живописного предмета. Так, его серия, посвященная Тукаю и образам его творений, насчитывает более ста работ, а цикл «Шурале» - более полусотни. А. Фатхутдинов написал также циклы «Татарское кладбище», «Обереги», «Обереги в лунной ночи», «Третированные». Писал художник и пейзажи, портреты, бытовые сцены из деревенской жизни.

Его живописные произведения созданы по преимуществу в манере примитива. Есть в них признаки соц-арта, что сообщают им иллюзию простоты, лаконизма художественного высказывания. Такая манера хорошо соответствует незатейливым сюжетам, придает нарочитую грубоватость объектам изображения: сельским пейзажам, лицам, деталям быта. Нередко художник обращался к языческим, библейским, домусульманским временам, что также стимулировало, по-видимому, их осмысление в манеpe примитива, порождало диалог с африканскими, индейскими культурами, с татарским фольклором. Простота и «наивность» их образно-выразительных систем позволяла заглядывать в некие истоки человеческого существования, искать в них первопричины человеческого существования, его соотнесенности с мирами природы, богов, мистических измерений.

Изложенное в равной мере относится и к скульптурным творениям А. Фатхутдинова. В них то же стремление увидеть действительность в ее первозданности, нетронутости никакими ухищрениями культуры. Выбор дерева в качестве основного материала позволял, очевидно, вступить в непосредственное сотворчество с самой природой, создавать произведение, руководствуясь только ее подсказками и собственной интуицией, которая оказывалась как бы сродни древнему человеку, способному разглядеть в фактуре дерева то лик и фигуру божества, то лицо человека или контуры животного. Резец скульптора привносит в них 
лишь минимум штрихов и акцентов, чтобы угадываемое природное творение как бы проступило на поверхностях дерева, отчетливее определилось в его наплывах, сучках, линиях, изломах и иных деформациях.

Все эти поиски ярких и органичных для создаваемых образов выразительных средств отвечали духу предперестроечного и перестроечного времени. Пластические языки советского искусства активно обновлялись, часто используя открытия западноевропейского модернизма, русского авангарда. Эти процессы происходили не только в столицах (Москве и Санкт-Петербурге), но и в провинции, о чем свидетельствует, к примеру, монография Р. Р. Султановой о творчестве художников «новых городов» Татарстана. Для России это были достаточно свежие веяния. Они обеспечивали интерес зрителей и высокие оценки искусствоведов. Во многом благодаря этому творчество А. Фатхутдинова получило признание, частично утратив статус творчества художникапровинциала. Вершиной признания стало присвоение Государственной премии им. Г. Тукая в 1993 году за серию работ по мотивам национального эпоса «Ияләр» («Обереги»).

Творчество А. Фатхутдинова всегда будило любопытство не только искусствоведов, но и журналистов, ученых. Свидетельство тому многочисленные публикации в периодической печати Татарстана («Туган як», «Нижнекамская правда», «Мәдәни жомга», «Казан утлары», «Ватаным Татарстан», «Татар иле», «Сөембикә», «Известия Татарстана» и др.). Там опубликованы живые впечатления о выставках художника, интервью с ним, интересные размышления о циклах, об отдельных произведениях, факты из биографии, наблюдения за особенностями живописной манеры, размышления о национальных чертах его творений. Все эти публикации - несомненное свидетельство интереса зрителей к образам и идеям, воплощенным в работах талантливого человека.

Но преимущественный интерес искусствоведов к «национальной проблематике» произведений А. Фатхутдинова или его художественно-пластическому языку, на мой взгляд, сильно ограничил, сузил тот реальный диапазон, который есть в творениях этого автора, не позволил, как уже неоднократно формулировалось в этой статье, охарактеризовать его истинный масштаб и уникальность. Поэтому необходимо искать новые подходы, вырабатывать та- кие исследовательские стратегии, которые позволили бы наиболее глубоко и адекватно самому предмету изучения раскрыть его наиболее характерные сущностные черты.

Данная статья - лишь первый и пока осторожный шаг в этом направлении. «Характеристика творчества» А. Фатхутдинова, выявление в этом творчестве каких-либо универсальных черт не являлись главной задачей. Нужно было пока на одном примере углубиться в мир смыслов и проблем, которые волновали автора «Өмет», чтобы наметить только первый штрих в новом подходе к исследованию его оригинального и очень масштабного мышления средоточия художественных миров любого творца.

\section{Литература}

Валеев В. Х. Народное декоративное искусство Татарии. Казань: Татар. кн. изд-во, 1984. 171 с.

Валеева Д. Мистический мир Ахсана Фатхутдинова // Казанский альманах. 2015. № 15 С. 156-160.

Валеева-Сулейманова $Г$. $Ф$. Монументальнодекоративное искусство Советской Татарии. Казань: Татарское кн. изд-во, 1984. 120 с.

Кьеркегор С. Философские крохи, или Крупицы мудрости / пер. Д. А. Лунгиной. М.: Институт философии, теологии и истории св. Фомы, 2009. 192 с.

Нигматуллина Ю. Г. «Запоздалый модернизм» в татарской литературе и изобразительном искусстве. Казань: Фэн, 2002. 175 с.

Нигматуллина Ю. Г. Татавангард и современный цивилизационный процесс. Казань: Фән, 2011. 68 с.

Нигматуллина Ю. Г. Татавангард как элемент срединной культуры // Tatarica. 2014. № 1 (2). 156178.

Нигматуллина Ю. Г. Татавангард: национальные художественные традиции как интегративный фактор в диалоге различных стилей // Tatarica. 2015. № 2 (5). 165-188.

Сартр Ж.-П. Бытие и ничто: Опыт феноменологической онтологии / пер. с фр., предисл., примеч. В. И. Колядко. М.: Республика, 2000. 640 с.

Султанова Р. Р. Искусство новых городов Республики Татарстан (1960-1990 гг.). Живопись, графика, монументально-декоративное искусство, скульптура. Казань, 2001. 192 с.

Файнберг А. Б. Художники Татарстана. Л.: Художник РСФСР, 1983. 232 с.

Хайдегzер M. Бытие и время. М.: Ад Маргинем, 1997. 452 с.

Червонная C. M. Художники Татарии. Казань: Тат. кн. изд-во, 1974. 75 с.

Шагеева Р. Г. Ахсан Фатхутдинов. Казань: Рухият, 2002. $220 \mathrm{c}$. 


\title{
ГАЛӘМ СЕРЛӘРЕН КУЗӘТУДӘ Ә. ФӘТХЕТДИНОВ («ӨМЕТ» КАРТИНАСЫНА ГЕРМЕНЕВТИК АНАЛИЗ ЯСАУ ТӘЖРИБӘСЕ)
}

\author{
Светлана Викторовна Синцова, \\ Россия, 420066, Казан ш., Чистай ур., 7 нче йорт, 19 нчы фатир,
} esintsov@mail.ru.

Мәкаләдә Әхсән Фәтхетдинов рәсемнәренең үзенчәлекле сыйфатларын билгеләүгә яңача якын килү омтылышы ясалды: әсәрләренең мәгънәләре системасы тикшерелде. Мондый герменевтик алымның кирәкле һәм нәтижәле булуы «Өмет» картинасын тирәнтен тикшеру аша нигезләнә.

Тематикага, образлар системасына, сәнгатьле сурәтләү чараларына, реципиентның мөмкин булган реакцияләренә комплекслы анализ ясалды. Бу юл рәссамның кеше яшәеше мәгънәсе, аның кыйммәтләре, алар нигезендә буыннар дәвамчанлыгы, кешеләрнең жирдәге яшәеше белән һәрвакыт янәшә барган теге дөнья, мистик үлчәнешләр белән әңгәмәсенең серле формалары, хәтта провинция һәм башкала мөнәсәбәтләре хакындагы үзенчәлекле күзаллауларының тирән һәм динамик дөньясын чагылдыра торган мәгънәләрнең катлаулы, фәлсәфи һәм мистикага юнәлгән системасы турында нәтижә ясарга мөмкинлек бирде.

Мондый күзәтүләр Ә. Фәтхетдиновның сәнгать ачышлары белән фәлсәфәчеэкзистенциалистлар идеяләре арасында параллельләр үткәрергә, әлеге аналогияләрнең чикләрен билгеләргә дә мөмкинлек бирде.

Мәкаләдә шулай ук Ә. Фәтхетдиновның тәржемәи хәленнән төп фактлар бәян ителде һәм сәнгать манерасының иң үзенчәлекле сыйфатлары билгеләнде.

Төп төшенчәләр: рәсем сәнгате, Әхсән Фәтхетдинов, «Өмет» картинасы, герменевтик анализ, комплекслы метод, экзистенциализм, мистицизм, яшәеш, Алла Тәңре. 